\title{
KEPUTUSAN HAKIM SYARIE DALAM KES-KES PENGESAHAN HIBAH RUQBA
}

\author{
Sharia Judges Decision on Cases of Hibah Ruqba Endorsement
}

\author{
NURUL SYUHADAH BinTI AZALAN \\ NOOR LIZZA BINTI MOHAMED SAID
}

\begin{abstract}
ABSTRAK
Permohonan kes pengesahan hibah di Mahkamah Syariah meliputi isu hibah ruqba. Di Mahkamah Syariah, Hakim-hakim Syarie akan membuat keputusan bagi kes-kes pengesahan hibah dengan berpandukan kepada kitab-kitab fiqh sedangkan terdapat pelbagai pendapat dalam kalangan fuqaha mengenai hibah termasuk berkaitan dengan isu hibah ruqba. Konsep hibah ruqba yang berbeza dengan kaedah asal hibah menjadi persoalan yang perlu dirungkai. Timbul juga persoalan adakah hibah ruqba dibolehkan menurut pendapat para fuqaha di samping melihat pengamalan hibah ruqba di Malaysia. Justeru, artikel ini adalah bertujuan untuk mengetahui keputusan yang dibuat oleh Hakim-hakim Syarie di samping mengetahui kecenderungan penghakiman Hakim-hakim Syarie dalam mengguna pakai pandangan fuqaha bagi menyelesaikan kes-kes pengesahan hibah mengenai isu hibah ruqba di Mahkamah Syariah. Data-data kajian ini diperoleh daripada laporan-laporan kes di Mahkamah Syariah, perbandingan mazhab dan temubual Hakim-hakim Syarie. Hasil kajian mendapati terdapat perbezaan pandangan daripada Hakim-hakim Syarie dalam menentukan keputusan kes-kes pengesahan hibah mengenai isu hibah ruqba seperti keputusan yang dibuat oleh Hakim Syarie yang telah meluluskan pengesahan hibah. Oleh yang demikian, dengan mengetahui keputusan Hakim Syarie dalam memutuskan isu hibah ruqba, ia dapat memberi garis panduan kepada masyarakat dan syarikat-syarikat yang menawarkan produk hibah.
\end{abstract}

Kata kunci: ruqba, Mahkamah Syariah, hibah, Hakim Syarie, keputusan

\begin{abstract}
ABSRACT
Application of endorsement of hibah in the Shariah Court includes the issues of hibah ruqba. At the Shariah Court, the Shariah Court's judges usually decided the cases of endorsement of the hibah based on the Islamic jurisprudence books even though there are various opinions among the Islamic jurists concerning the hibah, including the issue of ruqba. The difference between hibah ruqba concept and primary method of hibah needs clarification. There are issues of the validity of the ruqba in accordance with Islamic jurists' opinion and its practice in Malaysia. Thus, this article aims to analyse the judgments made by the Shariah Court's judges while adjudicating the issue of the hibah ruqba. The data was collected from relevant reported cases in the Shariah Court, opinions from various mazhabs and interviews conducted with the Shariah Court's judges. The research discovered that the Shariah Court's judges differed in adjudicating cases of endorsement of hibah ruqba. Therefore, understanding the judges' decisions in hibah ruqba cases might provide guidelines to society and service providers of hibah products.
\end{abstract}

Keyword: ruqba, Shariah Court, hibah, Shariah Judges, judgement 


\section{PENDAHULUAN}

Berdasarkan konsep asal, hibah adalah pemberian ketika hidup dan dilakukan secara sukarela. Melihat kepada cabang hibah yang ditetapkan oleh fuqaha, hibah terbahagi kepada dua jenis iaitu hibah mutlak dan hibah dengan syarat. Hibah dengan syarat dibahagikan kepada tiga jenis iaitu hibah dengan syarat balasan atau gantian, hibah dengan syarat ${ }^{c} u m r a$ dan hibah dengan syarat ruqba. Artikel ini akan memfokuskan dengan lebih mendalam mengenai hibah ${ }^{c}$ umra dan hibah ruqba.

Hibah merupakan salah satu instrumen dalam perancangan harta semasa hidup pemberi hibah dan ia cukup signifikan untuk diamalkan oleh umat Islam di Malaysia. Hibah ruqba merupakan salah satu isu yang kebiasaannya dibahaskan oleh para fuqaha dan dihuraikan secara panjang lebar dengan meneliti jenis dan bentuk akad. Isu hibah dengan syarat balasan atau gantian wujud apabila terdapat produk hibah yang telah ditawarkan di pasaran. Hibah dengan syarat balasan atau gantian ini juga telah diaplikasikan di dalam Undang-undang Sivil Jordan (Noor Lizza 2012: 311).

Berdasarkan pandangan jumhur fuqaha, akad hibah tidak mengharuskan syarat secara ${ }^{c}$ umra dan ruqba. Walau bagaimanapun, keputusan Mesyuarat Suruhanjaya Sekuriti Syariah telah mengharuskan hibah ruqba dalam pelaksanaan borang akuan hibah untuk transaksi yang melibatkan akaun bersama tabung unit amanah bagi akaun yang dipegang oleh orang Islam. Hibah ruqba telah digunakan dalam kontrak hibah amanah secara Islam bagi membolehkan pemberi hibah menerima semula harta yang telah dihibahkan kepada penerima hibah sekiranya penerima hibah meninggal dunia (Ahmad Hidayat 2006: 41). Di samping itu, menurut Naziree Md. Yusof (2009: 18), aplikasi hibah ruqba adalah paling relevan untuk dilaksanakan dalam masyarakat pada hari ini sebagai alternatif kepada masalah harta pusaka yang terbeku di Amanah Raya Berhad sehingga mencecah RM40 billion.

Faktor perselisihan di kalangan fuqaha mengenai hibah ruqba adalah disebabkan wujudnya unsur gharar yang terdapat dalam akad hibah ruqba. Berdasarkan konsep hibah ruqba, sekiranya ingin mendapatkan barang yang dihibahkan oleh pemberi hibah maka hendaklah menunggu kematian salah satu pihak yang berakad. Apabila pemberi hibah atau penerima hibah meninggal dunia, barulah pihak yang satu lagi boleh mendapat barang yang telah dihibahkan kepadanya sedangkan menunggu kematian salah satu pihak itu merupakan penggantungan yang tidak pasti (Noor Lizza 2014: 91).

Hibah turut diadaptasikan sebagai konsep tambahan kepada produk-produk takaful dan diamalkan oleh kebanyakan pengendali takaful seperti produk Pelan Pendidikan oleh Takaful Ikhlas Sdn. Bhd. Menerusi kaedah cadangan hibah yang diaplikasikan oleh syarikat takaful, peserta takaful akan mengisi borang cadangan hibah dan meletakkan nama individu yang akan menjadi benefisiari kepada manfaat takaful beliau. Hibah tersebut hanya cadangan iaitu apabila berlaku kematian sebelum tempoh matang, tabung tabarru $^{c}$ akan menghibahkan kepada benefisiari yang dicadangkan, tambahan pula hanya boleh dihibahkan kepada ahli keluarga sahaja (Alias et al. 2015: 145).

Majlis Penasihat Syariah Bank Negara Malaysia telah membuat keputusan bahawa hibah ke atas manfaat adalah diharuskan selagi mana ia merupakan hak milik peserta takaful. Maka, hibah tersebut ialah hibah bersyarat iaitu penama akan memiliki manfaat 
takaful apabila peserta takaful meninggal dunia. Jika peserta masih hidup dan takaful tersebut telah cukup tempoh matang, maka sijil takaful akan menjadi milik peserta. Oleh yang demikian, ini menunjukkan bahawa syarat yang ditentukan menyerupai syarat hibah ruqba kerana pemilikan manfaat harta hibah disyaratkan hanya dimilki oleh penerima hibah sekiranya peserta takaful manfaat meninggal dunia. Majoriti fuqaha berpandangan bahawa syarat ini adalah batal walaupun pemberian tersebut sah (Nasrul Hisyam 2011: 223).

Dalam pada itu, terdapat beberapa produk takaful yang menggunakan produk hibah yang dilaksanakan dalam dua bentuk iaitu hibah sesuatu yang ada dan hibah sesuatu yang ada tetapi berkuatkuasa selepas kematian peserta. Hibah sesuatu yang ada adalah harus dan tidak bercanggah dengan hukum syarak berlainan dengan hibah dalam bentuk yang kedua. Hibah yang dimaksudkan di sini ialah hibah manfaat takaful kepada penama yang dinyatakan oleh peserta melalui borang yang telah dilengkapkan olehnya. Hibah jenis ini dibahaskan secara panjang lebar oleh ulama kontemporari tempatan. Antara punca perselisihan ialah hibah sesuatu yang belum wujud, permasalahan qabd, status manfaat takaful, status hak mendapat manfaat takaful dan hukum-hakam berkaitan wasiat dan faraid (Mohd Zamerey 2008: 213).

Oleh yang demikian, isu-isu tersebut merupakan persoalan yang perlu diselesaikan. Justeru artikel ini akan membincangkan berkaitan pendapat fuqaha mengenai isu hibah ruqba dan juga kecenderungan keputusan yang dibuat oleh Hakim Syarie sama ada berpandukan kepada pendapat-pendapat mazhab sunni atau pendapat fuqaha selain mazhab sunni supaya boleh diaplikasikan bersesuaian dengan keadaan masa kini kerana kesahan hibah adalah bergantung kepada keputusan yang dibuat oleh Hakim Syarie. Justeru, penulis mengharapkan kajian ini dapat membantu dan memberi panduan kepada masyarakat di Malaysia bagi menghasilkan produk hibah dengan lebih terancang dan lebih memberi manfaat kepada pihak-pihak yang terlibat supaya ianya menepati hukum syarak.

\section{PERBAHASAN FUQAHA MENGENAI HIBAH ${ }^{C} U M R A$ DAN HIBAH $R U Q B A$}

Sebelum menjelaskan mengenai hibah ruqba lebih mendalam, penulis ingin menerangkan dahulu mengenai hibah ${ }^{c}$ umra kerana hibah ${ }^{c}$ umra merupakan cabang daripada hibah dengan syarat sepertimana hibah ruqba.

\section{Hibah ${ }^{c}$ Umra}

${ }^{c}$ Umra diambil daripada perkataan arab iaitu camara yang bermaksud sepanjang hidup (Ibn Manzur t.th.: 277). Manakala ${ }^{c}$ umra pula membawa maksud pemberian kepada seseorang sepanjang hidup pemberi atau sepanjang hidup penerima pemberian itu. Contoh lafaz daripada pemberi hibah yang menunjukkan kepada hibah dengan syarat ${ }^{c}$ umra ialah "aku berikan rumah ini selama hidupmu dan jika engkau mati maka rumah tersebut kembali kepadaku jika aku masih hidup dan kembali kepada warisku setelah aku mati" (Ibn Manzur t.th.: 278). 
Para fuqaha berselisih pendapat tentang kesahihan akad hibah dengan syarat ${ }^{c}$ umra. Antaranya ialah:

1. Menurut Imam Abu Hanifah, Imam al-Shafici dan Imam Ahmad di dalam qawl jadid berpendapat bahawa akad hibah adalah sah namun syaratnya batal (Ibn Qudamah t.th.: 689; Ibn Hazm t.th.: 131). Menurut mazhab Shafi $i$, syaratnya adalah sia-sia dan tiada nilai yang boleh membawa kepada tujuan pemberian tersebut (al-Jaziri 2003: 264). Begitu juga pandangan daripada mazhab Hanbali yang berpendapat sedemikian (Ibn Qudamah t.th.: 687).

Hujah ini berdasarkan hadis yang diriwayatkan oleh Abu Hurairah:

$$
\text { العُمرَى جائزةٌ }
$$

Maksudnya: 'Umra diharuskan (al-Bukhari, Kitab al-Hibah wa fadliha wa al-tahrid 'alayha, Bab Ma qila fi al-' Umra wa al-Ruqba, no. hadis 2445).

Mereka juga berhujah dengan hadis yang diriwayatkan oleh Jabir bin Abdillah:

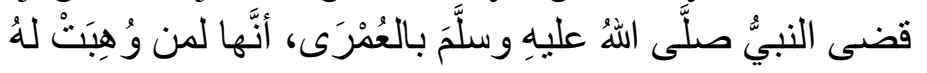

Maksudnya: Rasulullah SAW mengatakan berkaitan dengan ${ }^{c}$ umra iaitu ${ }^{c}$ umra adalah mengenai milik bagi orang yang diberikan kepadanya (al-Bukhari, Kitab al-Hibah wa fadliha wa al-tahrid ${ }^{\mathrm{c}}$ alayha, Bab Ma qila fi al- ${ }^{\mathrm{c}}$ Umra wa al-Ruqba, no. hadis 2444).

Mereka juga berhujah berdasarkan hadis ini iaitu:

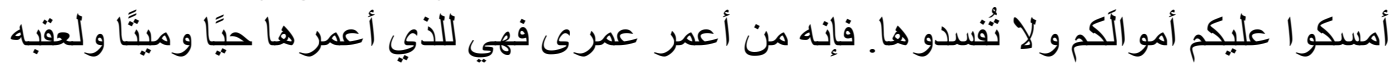

Maksudnya: Peganglah harta kamu dan janganlah kamu merosakkannya. Siapa yang memberikan ${ }^{c}$ umra maka itu adalah milik orang yang diberikan ${ }^{c} u m r a$ itu baik dia hidup atau mati dan juga keturunan selepasnya (Muslim bin al-Hajjaj, Sahih Muslim, Kitab al-Hibah, Bab al-'Umra, No. hadis 1625).

Hadis ini menunjukkan bahawa hibah dengan syarat ${ }^{c} u m r a$ adalah dibenarkan namun syaratnya dikira fasid. Maka implikasi daripada lafaz hibah dengan syarat ${ }^{c}$ umra tidak akan diguna pakai. Oleh yang demikian, harta tersebut tetap menjadi milik penerima hibah.

2. Menurut Imam Malik dan al-Layth, hibah dengan syarat ${ }^{c}$ umra ini adalah sah (Ibn Qudamah t.th.: 687; Ibn Hazm t.th.: 131). Menurut golongan ini, mereka berpendapat bahawa hibah yang disyaratkan selama orang yang diberi masih hidup termasuk hibah manfaat. Contohnya, harta tersebut adalah rumah, maka ia bermaksud pemberi hibah memberikan tempat tinggal kepada orang lain sepanjang hidupnya. Apabila pemberi hibah mati, maka harta tersebut hendaklah kembali kepada waris pemberi hibah (Ibn Rushd 2012: 2031).

Mereka berhujah dengan riwayat daripada Abd Rahman bin al-Qasim bahawa beliau mendengar hujah Makhul al-Damashqi bertanya kepada al-Qasim bin Muhammad tentang pemberian seumur hidup. Maka al-Qasim berkata: "Saya tidak mendapati manusia selain mereka berpegang kepada syarat-syaratnya mengenai harta mereka dan pada apa yang mereka berikan" (al-Shafici 2001: 132).

Di samping itu, terdapat juga hadis yang diriwayatkan oleh Jabir RA bahawa Rasulullah SAW bersabda: 


\section{العمرى جائزة}

Maksudnya: ${ }^{c}$ Umra itu diharuskan (al-Bayhaqi, Kitab al-Hibat, bab al- ${ }^{c}$ Umra. No hadis 11971).

3. Menurut Imam Shafici dalam qawl qadim, Abu Thawr dan Dawud, mereka berpendapat sekiranya lafaz hibah menyebut hibah seperti, "harta ini adalah sepanjang umurku untukmu dan warismu", maka harta tersebut menjadi milik penerima hibah. Dengan erti kata lain, ${ }^{c}$ umra tidak berkuatkuasa. Sekiranya di dalam akad tidak memberitahu harta tersebut akan menjadi milik waris penerima hibah, maka setelah meninggalnya penerima hibah harta tersebut kembali kepada pemberi hibah atau waris pemberi hibah, maka hibah ${ }^{c}$ umra telah berkuatkuasa (Ibn Qudamah t.th.: 688; Ibn Rushd 2012: 2031; Ibn Hazm t.th.: 131).

Mereka berhujah berdasarkan hadis daripada Jabir:

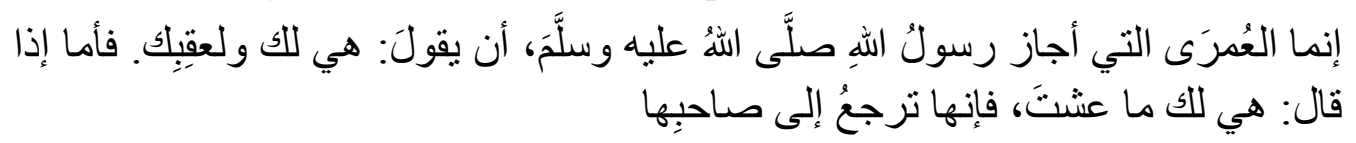

Maksudnya: Sesungguhnya ${ }^{c}$ umra yang diharuskan Rasulullah SAW bahawa seseorang berkata ini untuk kamu dan untuk keturunan kamu, maka apabila dia telah berkata ini untuk kamu selagi kamu hidup, maka ia akan kembali kepada pemiliknya (al-Bayhaqi, Kitab al-Hibat, bab al- ' Umra. No hadis 11971).

\section{Hibah Ruqba}

Ruqba bermaksud pemberian daripada seseorang kepada seseorang yang lain, kemudian apabila salah seorang meninggal dunia maka harta tersebut dikembalikan kepada pihak yang masih hidup (Ibn Manzur t.th.: 200).

Hibah dengan syarat ruqba turut berkait dengan tempoh waktu. Perbezaan antara hibah ruqba dengan ${ }^{c} u m r a$ ialah, ruqba menunggu waktu kematian salah satu pihak. Selagi mana salah satu pihak yang berakad tidak meninggal dunia, selagi itu pihakpihak berakad tidak dapat merasai harta yang dihibahkan itu. Pemilikan hibah tersebut pula akan diperolehi oleh pihak yang masih hidup. Contoh lafaz ayat bagi hibah ruqba ialah, "Jika aku mati sebelum kamu, harta ini menjadi milik kamu dan sekiranya kamu mati dahulu sebelum aku harta ini menjadi milik aku kembali". 'Umra pula berkaitan dengan sepanjang hayat umur pemberi hibah atau penerima hibah, ketika itu penerima hibah boleh menggunakan harta hibah. Sekiranya penerima hibah mati, pemberi hibah akan mendapat kembali harta hibah tersebut, manakala jika pemberi hibah yang mati harta akan diwarisi oleh waris pemberi hibah.

Ulama berselisih pendapat mengenai pengaplikasian hibah dengan syarat ruqba ini. Antara pendapat para fuqaha ialah:

1. Menurut Imam al-Shafici berdasarkan qawl qadim, Abu Hanifah, Imam Malik, alHasan, al-Sharbini dan al-Thawri, hibah dengan syarat ruqba adalah tidak sah (Ibn Qudamah t.th.: 690; al-Khatib 2003: 126; Ibn Rushd 2012: 2031). Ini adalah menurut pendapat jumhur fuqaha. Dengan erti kata lain, hibah dengan akad jenis ini adalah batal. Tambahan pula, hibah jenis ini boleh membawa kepada kemudaratan dan bahaya. Sesuatu pemilikan tidak diharuskan jika membawa kepada bahaya. 
Menurut Abu Hanifah dan Muhammad lafaz tersebut adalah akad pinjaman. Maka pemilikan secara akad pinjaman adalah tidak sah menurut pendapat ini. Tambahan pula, hibah ini berkait dengan kemungkinan sama ada akan terjadi atau sebaliknya sedangkan hibah tidak boleh dikaitkan dengan sesuatu kemungkinan (alZuhayli 1989: 9). Di samping itu, Rasulullah SAW mengharuskan hibah dengan syarat ${ }^{c} u m r a$ dan membatalkan hibah dengan syarat ruqba. Menurut Ibn Qudamah, hadis ini tidak diketahui dan tidak selamat (Ibn Qudamah t.th.: 690).

Menurut al-Zuhri, hibah dengan syarat ruqba adalah sah sebagai wasiat, maka hendaklah mengikut hukum wasiat (Ibn Qudamah t.th.: 690). Pendapat ini adalah bertepatan dengan hadis yang diriwayatkan oleh Ibn Abbas r.a:

$$
\text { لا رقبى فمن أرقب شيئا فهو سبيل الميراث }
$$

Maksudnya: Jangan melakukan ruqba, maka sesiapa melakukan ruqba terhadap sesuatu maka ia membuka kepada jalan pewarisan (al-Albani, Kitab al-' ${ }^{\mathrm{c}} \mathrm{mmra}$, no. hadis 3710 ).

2. Menurut Imam Shafici berdasarkan qawl jadid, Abu Yusuf, Imam Ahmad dan mazhab Hanbali, akad hibah adalah sah namun syarat secara ruqba adalah batal (alZuhayli 1989: 9; Ibn Qudamah t.th.: 689).

$$
\text { لا عُمرى و لا رُقبَى فمن أعمرَ شيئًا أو أرقبَه فهو للهُ حياتَه ومماتَهـ }
$$

Maksudnya: Janganlah kamu memberi secara ${ }^{c}$ umra dan ruqba, sesiapa yang memberi sesuatu secara ${ }^{c}$ umra atau ruqba maka itu akan menjadi miliknya sewaktu hidup dan mati (al-Albani, Kitab al- ${ }^{\mathrm{C}}$ Umra, no. hadis 3735).

Mereka juga berhujah dengan hadis yang diriwayatkan oleh Ibn Abbas r.a mengatakan bahawa:

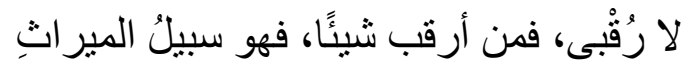

Maksudnya: Tiada ruqba, barang siapa membuat ruqba sesuatu harta, maka harta itu adalah jalan kepada pewarisan (al-Albani, Kitab al-Hibah, no. hadis 3710).

Oleh yang demikian, berdasarkan hujah di atas sesiapa yang membuat pemberian secara ruqba, maka harta tersebut akan menjadi milik penerima hibah dan sekiranya penerima hibah mati, harta itu dibahagikan melalui pembahagian pusaka kepada waris penerima hibah yang berhak.

3. Terdapat fuqaha yang mengharuskan ruqba ini iaitu seperti yang dinyatakan oleh alSuyuti di dalam Sunan al-Nasa'i. Beliau menjelaskan bahawa larangan yang dinyatakan di dalam hadis-hadis mengenai hibah ruqba bukan bermaksud larangan secara mutlak, tetapi ia adalah bermaksud 'tidak sewajarnya' dilakukan ruqba demi menjaga kepentingan pemberi hibah kerana pemberi hibah tetap tidak boleh menarik balik harta yang telah diserahkan itu seperti yang ditetapkan menurut kaedah umum (al-Sindi t.th.: 581). Oleh yang demikian, ini menunjukkan bahawa hibah dengan syarat ruqba ini sah kerana dengan syarat kematian baharulah harta tersebut kembali kepada pihak yang masih hidup, berdasarkan sabda Rasulullah SAW iaitu hadis yang diriwayatkan oleh Ibn Abbas r.a:

$$
\text { العمرى جائزة لمن أعمر ها، والرقبى جائزة لمن أرقبها، و العائد في هبته كالعائد في قبئه. }
$$


Maksudnya: Umra itu (hukumnya) harus, ruqba itu (hukumnya) harus, dan pemberi hibah yang menarik balik hibahnya seperti menjilat muntahnya kembali (al-Albani, Kitab al-Hibah, no. hadis 3712).

Berdasarkan sanad hadis ini, ada pakar hadis berpendapat bahawa semua perawi di dalam hadis ini adalah thiqah melainkan Muhammad bin Muslim bin Tadrus alQurayshi yang merupakan salah seorang perawi hadis ini disifatkan sebagai thiqah saduq yang bermaksud cenderung kepada lemah. Namun, al-Nasa'i dan Ibn Hibban menyifatkan beliau sebagai thiqah (al-Mizzi 1992: 402-409). Selain itu, dikuatkan lagi bahawa hadis ini boleh dijadikan sebagai hujah apabila al-Albani mengatakan hadis ini bertaraf sahih (al-Albani 1998: 576).

Berdasarkan hadis ini, 'umra dan ruqba adalah dibolehkan oleh Rasulullah SAW, bahkan hadis ini adalah berpandukan kepada sumber yang sahih. Di samping itu, menurut Ibn ${ }^{\mathrm{c}}$ Arabi, di sisi masyarakat Arab, pemilikan manfaat dibolehkan sekiranya ditukarkan oleh syarak kepada pemilikan secara ruqba seperti solat iaitu doa ditukarkan kepada perbuatan yang lain. Begitu juga pertukaran zihar dan ila' daripada hukum talak kepada hukum-hukum tertentu (Ibn Qudamah t.th.: 688).

Berdasarkan kajian yang dibuat di Mahkamah-mahkamah Syariah, masih tidak terdapat hibah dengan syarat ${ }^{\mathrm{c}} u m r a$ setakat ini. Namun begitu, hibah dengan syarat ruqba telah wujud dan terdapat beberapa kes yang telah dibicarakan di Mahkamah Syariah. Bagi melihat keputusan Hakim Syarie mengenai pengamalan produk hibah di Malaysia, maka keputusan dan penghujahan yang diputuskan oleh Hakim-hakim Syarie wajar diambil perhatian.

\section{KEPUTUSAN HAKIM-HAKIM SYARIE MENGENAI HIBAH RUQBA}

Produk hibah berkonsep hibah ruqba banyak diaplikasikan oleh syarikat-syarikat perniagaan di Malaysia sedangkan jumhur fuqaha berpendapat bahawa hibah jenis ini adalah tidak diharuskan. Dengan erti kata lain, hibah ruqba adalah sah tetapi syaratnya batal. Bagi melihat kesahan produk hibah ruqba ini, keputusan yang dibuat oleh Hakimhakim Syarie hendaklah dirujuk kerana hanya Mahkamah Syariah berbidang kuasa mengesahkan hibah yang dibuat oleh orang-orang Islam.

Antara kes-kes yang dibicarakan di Mahkamah Syariah mengenai isu hibah ruqba ialah kes Rafizah Binti Ab Karim v Kamar Bin Ab Karim dan Empat Defendan Yang Lain (10100-044-0478-2011). Fakta kes ini ialah ibu plaintif iaitu Lamah Binti Sa'at telah meninggal dunia pada 15 Mei 2011. Plaintif dalam tuntutan menyatakan bahawa ketika hayat ibunya, beliau telah membuat hibah secara bertulis melalui dokumen pengisytiharan hibah pada 20 Januari 2011 dengan menyatakan di dalam dokumen tersebut bahawa harta yang dihibahkan menjadi kepunyaan penerima hibah iaitu plaintif setelah ibu plaintif meninggal dunia. Dalam kes ini, plaintif telah memohon supaya mahkamah mengesahkan hibah yang dibuat oleh ibunya iaitu Lamah Binti Sa'at. Mahkamah mendapati bahawa terdapat isu mengenai hibah ruqba kerana di dalam lafaz yang diucapkan ketika akad hibah dikaitkan dengan kematian salah satu pihak. 
"Akad hibah antara pihak-pihak dikaitkan dengan kematian salah seorang pihak. Di dalam hibah ia dikatakan sebagai hibah ruqba."

Walau bagaimanapun, di dalam alasan penghakiman ini tidak diterangkan konsep pelaksanaan hibah ruqba secara jelas. Berdasarkan penghujahan yang dibuat, Hakim Syarie dalam kes ini merujuk kepada Keputusan Majlis Penasihat Suruhanjaya Syariah Sekuriti yang mengharuskan hibah ruqba dilakukan dalam pelaksanaan borang akuan hibah untuk transaksi yang melibatkan akaun bersama tabung unit amanah bagi akaun yang dipegang oleh orang Islam. Oleh yang demikian, keputusan bagi kes ini adalah hakim memutuskan hibah yang berkonsepkan hibah ruqba yang berlaku antara pemberi hibah dan penerima hibah melalui dokumen pengisytiharan hibah adalah sah.

Selain itu, kes Salmah Binti Osman v CIMB Islamic Trustee (14700-044-01502013). Fakta kes ini ialah Som Binti Abdullah telah menghibahkan hartanya kepada pemohon iaitu Salmah Binti Osman dan anak angkatnya iaitu Minah Binti Osman menerusi satu sighah hibah yang berkonsepkan hibah ruqba yang telah ditandatangani oleh pemberi hibah dan telah diakui oleh penerima-penerima hibah. Setelah itu, penerima hibah iaitu Minah Binti Osman meninggal dunia sebelum pemberi hibah meninggal dunia. Berdasarkan konsep hibah ruqba, sekiranya berlaku kematian salah satu pihak, harta hibah hendaklah dikembalikan kepada pihak yang masih hidup. Bertepatan dengan tindakan yang dilakukan oleh pemberi hibah dalam kes ini dengan cara mengambil semula harta tersebut dan memberikan kepada pemohon iaitu Salmah Binti Osman.

Timbul persoalan sama ada hibah yang berkonsepkan hibah ruqba itu sah atau tidak dan adakah sah harta hibah tersebut diberikan kepada pemohon iaitu Salmah Binti Osman? Hakim Syarie yang membicarakan kes ini berhujah bahawa pengaplikasian hibah ruqba hendaklah mengguna pakai pendapat jumhur fuqaha yang tidak mengharuskan hibah yang mensyaratkan pemilikannya pada suatu masa akan datang. Justeru, Hakim cenderung mengambil pendapat jumhur fuqaha yang berpendapat bahawa hibah ${ }^{c}$ umra dan ruqba ini adalah sah namun syaratnya batal kerana jika syarat itu diterima pakai maka ia bertentangan dengan kehendak akad itu sendiri. Sekiranya mengikut pendapat jumhur fuqaha, maka harta itu sepenuhnya menjadi milik wariswaris Minah Binti Osman dan tidak dikembalikan kepada Som Binti Abdullah.

Namun begitu, menurut penghujahan hakim dalam kes ini, harta hibah tersebut dikira harta wasiat berikutan berlakunya kematian kerana syarat itu terikat dengan perpindahan harta selepas berlakunya kematian Minah Binti Osman. Oleh yang demikian, Som Binti Abdullah mendapat harta wasiat daripada Minah Binti Osman dengan kadar satu pertiga daripada bahagian yang diperolehi daripada harta yang dihibahkan itu manakala dua pertiga menjadi milik waris-waris Minah Binti Osman mengikut pembahagian secara pusaka. Justeru, harta hibah yang diberikan oleh Som Binti Abdullah kepada Salmiah Binti Osman hanyalah setakat satu pertiga bahagian sahaja.

Hakim Syarie berpandangan bahawa terdapat kesan positif sekiranya harta tersebut mengikut wasiat iaitu dengan hanya mendapat $1 / 3$ bahagian daripada harta peninggalan tersebut. Ini adalah kerana berkemungkinan sama ada sedar atau tidak pewasiat akan menafikan harta peninggalannya kepada waris-waris yang berhak dengan melepaskan 
kesemua hartanya atau mengurangkan bahagian mereka sehingga menjejaskan kadar bahagian mereka.

Pada pandangan penulis, hakim tidak membatalkan syarat itu secara langsung kerana hakim tetap mengambil kira kandungan syarat tersebut dengan memutuskannya sebagai harta wasiat kerana syarat tersebut adalah mengenai pemberian harta selepas kematian penerima hibah. Oleh yang demikian, keputusan yang dibuat oleh Hakim Syarie ini adalah tidak mengikut pendapat jumhur fuqaha tetapi mengguna pakai pandangan yang dipegang oleh al-Zuhri.

Begitu juga kes Mohd Akbar Bin Shafawi v Fara Soraya Binti Tarmizi dan Khafil Rusyaidi Bin Kamarul Rasydan (06100-044-0473-2014). Pemohon dalam kes ini iaitu Mohd Akbar Bin Shafawi telah membuat permohonan di Mahkamah Tinggi Syariah Kuantan untuk mengesahkan hibah yang telah dibuat olehnya terhadap Responden pertama dan Responden kedua. Harta yang dihibahkan oleh pemohon adalah terdiri daripada harta alih dan harta tak alih. Berkaitan dengan isu hibah ruqba ini ialah terdapat harta manfaat takaful yang ingin dihibahkan oleh pemberi hibah. Hakim dalam kes ini membenarkan pengaplikasian hibah manfaat takaful. Konsep hibah manfaat takaful adalah bersamaan dengan hibah ruqba kerana ia dikaitkan dengan kematian peserta. Keputusan yang dibuat oleh Hakim Syarie dalam kes ini adalah berpandukan kepada keputusan mesyuarat ke-34 Majlis Penasihat Syariah Bank Negara Malaysia (BNM).

Oleh yang demikian, ketiga-tiga kes ini menunjukkan pengaplikasian hibah ruqba dibolehkan untuk diamalkan di Malaysia. Namun begitu, melihat kepada keadaan umat sekarang, keharusan pengaplikasian hibah ruqba boleh diterima pakai demi kemaslahatan umat manusia kerana ini merupakan satu inisiatif supaya pemberi hibah tidak hilang haknya untuk menguasai harta tersebut kerana bimbang kemungkinan penerima hibah akan mengabaikan haknya apabila semua harta diserahkan kepada penerima hibah. Begitu juga kenyataan yang dibuat oleh Y.A.A Ketua Hakim Syarie Pahang iaitu Dato Abdul Rahman Bin Md Yunos yang menerima prinsip hibah ruqba di Mahkamah Syariah (Abdul Rahman 2015: 160).

Menurut Nasrul Hisyam, syarat ruqba boleh diaplikasikan melalui akad pinjaman kerana berdasarkan hibah ini, penerima hibah boleh menggunakan manfaat namun belum lagi mendapat milikan ${ }^{c}$ ayn secara mutlak sehingga berlaku kematian salah satu pihak yang berakad. Bagi membezakan sama ada prinsip yang diguna pakai adalah hibah atau pinjaman, maka ia hendaklah berpandukan kepada niat pemberi hibah (Nasrul Hisyam 2011: 183). Selain itu, akad hibah yang dibuat dengan syarat ${ }^{c} u m r a$ dan ruqba ini adalah sah sekiranya kedua-dua pihak bersetuju dengan sukarela terhadap syarat tersebut serta unsur gharar yang wujud di dalam syarat tersebut diketahui oleh pihak-pihak yang berakad (Noor Lizza 2015: 102).

\section{KESIMPULAN}

Dalam perbahasan fuqaha mengenai isu hibah ruqba, para fuqaha berbeza pandangan namun bukan sebagai punca untuk membebankan manusia tetapi sebagai rahmat bagi umat manusia untuk mengaplikasikan pendapat para fuqaha yang bersesuaian dengan 
keperluan arus semasa masa kini. Isu hibah ruqba merupakan isu yang penting untuk dibincangkan kerana banyak produk hibah bersandarkan kepada syarat ruqba yang telah ditawarkan oleh syarikat-syarikat perniagaan. Rentetan daripada itu, bagi mengetahui produk hibah ruqba ini diterima pengamalannya di Malaysia maka hendaklah dirujuk keputusan Hakim-hakim Syarie berkaitan dengan isu ini kerana hanya Mahkamah Syariah yang berbidang kuasa mengesahkan hibah. Walau bagaimanapun, ini bukan bermakna Mahkamah Syariah mengaplikasikan 'doktrin duluan mengikat' seperti diguna pakai di Mahkamah Sivil. Namun, disebabkan ketiadaan undang-undang hibah maka kes-kes terdahulu tidak salah untuk dirujuk bagi menjadi panduan kepada Hakimhakim Syarie menentukan keputusan bagi kes-kes yang sedang dibicarakan. Tambahan pula, Jabatan Kehakiman Syariah Malaysia telah mengeluarkan pekeliling menerusi Arahan Amalan No.1 Tahun 2002 yang menyatakan bahawa keputusan berhubung isuisu, fakta dan undang-undang yang sama atau ada persamaan yang telah diputuskan oleh mahkamah yang lebih tinggi hendaklah dihormati oleh mahkamah yang lebih rendah. Melihat kepada keputusan yang berbeza yang dibuat oleh Hakim Syarie, maka rumusan yang dapat dibuat adalah berlakunya perbezaan keputusan disebabkan Hakim-hakim Syarie mengguna pakai pendapat-pendapat fuqaha yang berbeza. Pemilihan penggunaan pendapat-pendapat mazhab fiqh adalah berpandukan kepada situasi kes. Walau bagaimanapun, melihat kepada maslahah pada masa kini, kebanyakan Hakim Syarie menerima pengaplikasian hibah ruqba di Mahkamah Syariah di samping terdapat rujukan keharusannya daripada sumber yang sahih. Selain itu, penulis mencadangkan supaya undang-undang hibah hendaklah dikanunkan sebagai panduan dan rujukan Hakim-hakim Syarie bagi membuat penghakiman bagi kes-kes hibah di Mahkamah Syariah. Bagi syarikat-syarikat pengurusan harta orang Islam di Malaysia pula, mereka hendaklah memainkan peranan penting supaya produk yang dihasilkan adalah sejajar dengan keputusan Hakim Syarie kerana badan kehakiman merupakan institusi yang menentukan sama ada hibah yang dihasilkan itu adalah sah atau sebaliknya.

\section{PENGHARGAAN}

Artikel ini merupakan sebahagian daripada hasil kajian yang menggunakan dana penyelidikan GGPM-2015-024. 


\section{RUJUKAN}

Abdul Rahman bin Md. Yunos. 2015. Hibah dari Perspektif Aplikasi Undang-undang Syariah di Malaysia. Prosiding Seminar Hibah dalam Pengurusan Harta Islam, hlm. 156-161.

Ahmad Hidayat Buang. 2006. Pembentukan dan Pentadbiran Harta Amanah Menurut Perspektif Undangundang Islam. Dlm. Siti Mashitoh Mahamood (pnyt.). Pentadbiran Harta Orang-orang Islam di Malaysia, hlm. 172. Kuala Lumpur: Universiti Malaya.

al-Albani, Muhammad Nasir al-Din. 1998. Sahih Sunan al-Nasa'i. Jil.2. Riyad: Maktabah al-Ma ${ }^{\mathrm{c}}$ arif lil Nashr wa al-Tawzi ${ }^{\mathrm{c}}$.

Alias bin Azhar, Mohammad Azam Hussain, Muhammad Hafiz Badarulzaman \& Fauziah Mohd Noor. 2015. Instrumen hibah dalam takaful: Tinjauan di Syarikat Takaful Ikhlas Sdn, Bhd. Prosiding Seminar Hibah dalam Pengurusan Harta Islam, hlm. 142-149.

al-Bayhaqi, Abi Bakar Ahmad bin al-Husin bin ${ }^{\mathrm{c}}$ Ali. 2003. al-Sunan al-Kubra. Juz. 6. Beirut: Dar alKutub al- ${ }^{\mathrm{C}}$ Ilmiyah.

al-Bukhari, Abi Abdullah Muhammad bin Ismail. 2002. Sahih al-Bukhari. Damsyiq: Dar Ibn Kathir.

Ibn Hazm, Abu Muhammad ${ }^{\mathrm{c}}$ Ali bin Ahmad bin Sacid bin Hazm al-Andalusi. t.th. al-Muhalla bi al-Athar. Beirut: Dar a-Kutub al- ${ }^{\mathrm{C}}$ Ilmiyah.

Ibn Manzur, Jamal al-Din Muhammad bin Mukarram. 2003. Lisan al- ${ }^{c}$ Arab. Kaherah: Dar al-Hadith.

Ibn Qudamah, Abdullah bin Ahmad. t.th. al-Mughni. Juz. 5. Beirut: ${ }^{\mathrm{c}}$ Alam al-Kutub.

Ibn Rushd, Abi al-Walid Muhammad bin Ahmad bin Muhammad bin Rushd al-Andalusi. 2012. Sharh Bidayat al-Mujtahid wa Nihayat al-Muqtasid. Cet. 5. Jil. 4. Kaherah: Dar al-Salam.

al-Jaziri, Abd Rahman. 2003. al-Fiqh ${ }^{c}$ ala al-Madhahib al-Arbac ah. Cet. 2. Jil. 3. Beirut: Dar al-Kutub al${ }^{\mathrm{c}}$ Ilmiyah.

al-Khatib, Shamsuddin Muhammad bin Muhammad. 2003. al-Iqna ${ }^{c}$ fi Hal Alfaz Abi Shuja ${ }^{c}$. Juz. 2. Mesir: al-Maktabah al-Tawfiqiyah.

al-Mizzi, Jamal al-Din Abi al-Hajjaj Yusuf. 1992. Tahdhib al-Kamal fi Asma' al-Rijal. Juz. 26. Syria: Muasasah al-Risalah.

Mohd Zamerey Abdul Razak \& Shofian Ahmad. 2008. Pelaksanaan hibah dalam industri takaful: bentuk dan hukum. Dlm. Anwar Fakhri Omar et al. (pnyt.). Isu Fiqah dan Persoalan Semasa, hlm. 207219. Bangi: Universiti Kebangsaan Malaysia.

Muslim bin al-Hajjaj. 2006. Sahih Muslim. Cet. 1. Riyad: Dar Taybah.

Naziree bin Md. Yusof. 2009. Mekanisme Dokumen Wasiat Amanah Raya Berhad (ARB) dan Aplikasi Hibah Ruqba: Satu Analisis. Kanun Jurnal Undang-undang Malaysia, 21(3): 119.

Nasrul Hisyam Nor Muhamad. 2011. Hibah dalam Undang-undang Islam: Prinsip dan Amalan. Johor: Universiti Teknologi Malaysia.

Muslim bin al-Hajjaj. 2006. Sahih Muslim. Cet. 1. Riyad: Dar Taybah.

Noor Lizza Mohamed Said et al. 2012. Hibah dengan syarat balasan menurut pandangan fuqaha dan kedudukannya dalam undang-undang sivil Jordan. Jurnal Syariah, 20(3): 315-325.

Noor Lizza Mohamed Said. 2014. Analisis fiqah terhadap undang-undang hibah dan wasiat di negaranegara Islam. Tesis Dr. Fal. Bangi: Universiti Kebangsaan Malaysia.

Noor Lizza Binti Mohamed Said. 2015. Hibah ${ }^{c}$ Umra dan Hibah Ruqba. Prosiding Seminar Hibah dalam Pengurusan Harta Islam, hlm. 98-103.

al-Shafici, Muhammad bin Idris. 1997. al-Umm. Cet. 1. Juz. 5. Mansurah: Dar al-Wafa'.

al-Sindi. t.th. Sunan al-Nasa'i bi Sharh al-Hafiz Jalal al-Din al-Suyuti. Juz. 5. Beirut: Dar al-Ma'rifah.

al-Zuhayli, Muhammad. 1432H/2011. al-Mu'tamad fi Fiqh al-Imam al-Shafi ${ }^{c}$. Cet. 3. Juz. 3. Damshiq: Dar al-Qalam.

Nurul Syuhadah Binti Azalan

Pelajar Pascasiswazah

nurulsyuhadah20121@gmail.com

Jabatan Syariah,

Fakulti Pengajian Islam, 
Universiti Kebangsaan Malaysia, 43600 Bangi, Selangor,

MALAYSIA

Noor Lizza Binti Mohamed Said lizza@ukm.edu.my

Jabatan Syariah,

Fakulti Pengajian Islam,

Universiti Kebangsaan Malaysia, 43600 Bangi, Selangor,

MALAYSIA 
Journal of Contemporary Islamic Law

Vol. 1(2) (2016)

\section{Editor-In-Chief}

Dr. Mohd Al Adib Samuri

\section{Co-Editor}

Dr. Salmy Edawati Yaacob

\section{Senior Editors}

Prof. Dr. Abdul Basir Mohamad Prof. Dr. Mohd Nasran Mohamad Assoc. Prof. Dr. Shofian Ahmad Assoc. Prof. Dr. Zaini Nasohah Assoc. Prof. Dr. Ibnor Azli Ibrahim Assoc. Prof. Dr. Zuliza Mohd Kusrin

Chief Managing Editor

Dr. Mat Noor Mat Zain

Arabic Copy Editor

Anwar Fakhri Omar

\section{Bahasa Copy Editor}

Dr. Mohd Zamro Muda

Md. Yazid Ahmad

\section{Editor}

Dr. Mohammad Zaini Yahaya Nik Abd. Rahim Nik Abdul Ghani 
Journal of Contemporary Islamic Law

Vol. 1(2) (2016)

Published by:

Jabatan Syariah,

Fakulti Pengajian Islam,

Universiti Kebangsaan Malaysia,

43600 Bangi, Selangor,

MALAYSIA

Suggested citation style

Author, (2016), Title, Journal of Contemporary Islamic

Law, 1(2), pages, http://www.ukm.my/jcil

eISSN 0127-788X

This work is licensed under a Creative Commons Attribution-Noncommercial-No Derivative Works 3.0 Unported License

(http://creativecommons.org/licenses/by-nc-nd/3.0/).

You can download an electronic version online. You are free to copy, distribute and transmit the work under the following conditions: Attribution - you must attribute the work in the manner specified by the author or licensor (but not in any way that suggests that they endorse you or your use of the work); Noncommercial you may not use this work for commercial purposes; No Derivate Works - you may not alter, transform, or build upon this work. 